\title{
Roger Nicoll Tackles Learning/Disabilities
}

\author{
(1DTeresa Esch
}

DOI:http://dx.doi.org/10.1523/ENEURO.0071-14.2015

Science Writer, Society for Neuroscience

Key words: long-term potentiation; synaptic plasticity

\section{Significance Statement}

Roger Nicoll was doubly honored by the Society for Neuroscience this year. He was awarded the Ralph W. Gerard Prize in Neuroscience in recognition of his many contributions to our understanding of neuromodulation and long-term potentiation, and he was selected to give the Albert and Ellen Grass Lecture at the Society's annual meeting. This commentary provides an overview of Nicoll's work and his remarkable personal history, which he recounted in his talk.

This year, the Society for Neuroscience awarded its highest honor, the Ralph W. Gerard Prize in Neuroscience, to Roger Nicoll and Richard Tsien. This prize is awarded to scientists who have made outstanding contributions to neuroscience throughout their careers. Roger Nicoll received the additional honor of being invited to discuss his work in the Albert and Ellen Grass Lecture. He used the opportunity not only to discuss his most recent work, but also to express his deep gratitude for the recognition, through a moving personal account of the "improbable journey" he took "to end up on this stage and to be on this list of really distinguished people."

\section{The Public Record: Nicoll's Scientific Accomplishments}

Nicoll began his neuroscientific career at St. Elizabeths Hospital in Anacostia, working first with Gian Salmoiraghi and later with Floyd Bloom, who were using five-barrel electrodes to identify neurotransmitters used by different neurons. There, Nicoll obtained some of the first evidence that GABA is a neurotransmitter in the vertebrate CNS and that sedative hypnotics and general anesthetics greatly prolong GABA transmission. These findings were pub-

\footnotetext{
Received December 14, 2014; accepted December 16, 2014; First published December 18, 2014.

Correspondence should be addressed to Teresa Esch, 2307 Rosedown Drive, Reston, VA 20191. E-mail: tesch@alumni.virginia.edu.

DOI:http://dx.doi.org/10.1523/ENEURO.0071-14.2015

Copyright (C) 2015 Esch and Nicoll

This is an open-access article distributed under the terms of the Creative Commons Attribution License Attribution-Noncommercial 4.0 International which permits noncommercial reuse provided that the original work is properly attributed.
}

lished as three single-author papers (Nicoll, 1969, 1970a, $1970 b)$. This work opened the door to several productive years spent investigating the neuromodulatory effects of neurotransmitters.

Studying the long-term changes produced by neuromodulation eventually led Nicoll to work on long-term plasticity. He and his colleagues have contributed enormously to our understanding of the molecular events underlying long-term potentiation (LTP), starting with the demonstration that it selectively affects postsynaptic AMPA receptor currents (Kauer, et al. 1988). Shortly afterward, the group showed that LTP requires calcium influx through NMDA receptors and activation of calcium/ calmodulin-dependent protein kinase II (CAMKII; Malenka et al., 1988, 1989). Later work included the discovery of "silent synapses" that contain NMDA but not glutamate receptors (Isaac et al., 1995) and identification of proteins that regulate AMPA receptor distribution, such as stargazin (Chen et al., 2000).

Work by Nicoll and others has revealed that LTP involves the accumulation of AMPA receptors in the postsynaptic density (PSD), but how this occurs is still unknown. At least three hypotheses have been put forth. One, the capture model, posits that CAMKII activation leads to the formation of "slots" in the PSD, and that these slots then capture freely diffusing AMPA receptors. A related model, the modification model, proposes that CAMKII leads to modification of freely diffusing AMPA receptors so they can be captured by slots. A third model, the insertion model, suggests that CAMKII activation leads to insertion of newly synthesized AMPA receptors. 
To distinguish between these models, it will be necessary to identify the targets of CAMKII.

Some of the most recent efforts to identify CAMKII targets have been made by Nicoll's postdoc Bruce Herring. He has examined the roles of two guanine nucleotide exchange factors that activate Rho-GTPases. These molecules, Kalirin7 and Trio9, were previously shown to be localized to the PSD and to be phosphorylated by CAMKII. Nicoll presented as-yet-unpublished work showing that overexpressing Kalirin7 or Trio9 doubled the AMPAreceptor-mediated component of EPSCs in hippocampal slices, while knocking down either protein reduced AMPA currents. Furthermore, expressing mutant forms of these proteins that cannot be phosphorylated by CAMKII prevented LTP induction.

\section{The Private History: Nicoll's Difficult Journey}

That Roger Nicoll would contribute so greatly to our understanding of the basic mechanisms of synaptic transmission and the molecular bases of learning was almost certainly not predicted by his grade school and high school teachers. In fact, he was considered at best average and at worst feeble-minded. Why? He has severe dyslexia, which greatly impaired his reading ability. On his first IQ test, he scored 70-the upper bound for intellectual disability - because his reading difficulties prevented him from getting through the entire test. Although the school psychologist subsequently allowed him to take an untimed test on which he did much better, becoming a university professor seemed out of the question.

Dyslexia results from improper synaptic wiring that cannot be corrected. Nonetheless, with much effort, one can learn alternative strategies that (as Nicoll demonstrates) can allow one to achieve great success. But when he was a child, dyslexia was equated with mental impairment, and it carried a stigma that Nicoll found crippling. Despite his best efforts to hide his disability, he was subjected to ridicule that pummeled his self-esteem. He felt that he had more to offer than what others could see, and he found it deeply frustrating that they could not see his potential.

Not all of Nicoll's grades were poor, however; he did well in classes that did not depend heavily on reading, notably mechanical drawing and science. But there were many Cs and Ds, and even an F (in driver's education; he assured the audience that he is a good driver now). And his SAT scores were exactly average. Noting that he got the same middling score when he took a practice SAT with his son a few years ago, he concluded that standardized tests are great predictors of one's future performance on such tests. But Nicoll clearly is pained by the thought that other young people may have accepted the "intellectual death sentence that these tests provide."

Because of his mediocre grades and SAT scores, none of the colleges Nicoll applied to accepted him. Prompted by an ad, he submitted his application to a pool of colleges looking for unusual candidates. One of the colleges that saw potential in Nicoll was Lawrence University, which he chose to attend. He remains grateful to Lawrence for taking a chance on him-despite being greeted upon his arrival by the head of admissions, who recognized him as "the one with the low SAT scores."

Nicoll continued to struggle with his coursework in college, and he was put on academic probation after his first year. He had one semester to get his grade point average up to a $\mathrm{C}$. This was a turning point for him, because in desperation, he decided to take two semesters of Biology over the summer. Not surprisingly, he did very well, and his confidence gained considerable strength. This new confidence (and deferring classes that required reading) helped him get through college with a grade point average of 2.5 .

Things vastly improved for Nicoll once he started medical school at the University of Rochester. Yes, he managed to get accepted to this prestigious institution. He speculates that the source of this good fortune was his mother, who "was a very eloquent and very forceful writer. And she wrote my essay." In his studies, he learned of the medical advancements that came with the identification of neurotransmitters and their receptors in the PNS, and he saw the promise that the eventual identification of CNS transmitters held for treating schizophrenia, depression, and other mental illnesses. And so he fell in love with neuroscience. He decided to spend a "monastic" year working at St. Elizabeths Hospital, where he demonstrated that GABA is a neurotransmitter in the olfactory bulb. Despite all his earlier struggles, this experience convinced him that he could do experiments at least as well as anyone else, and with more confidence than ever, he was empowered to pursue a career in neuroscience.

Despite his many accomplishments, however, Nicoll admits that he still has "lingering demons" from his childhood. In his closing remarks, he again expressed his gratitude for the Gerard Prize, which helped silence those demons. With this, Dr. Nicoll was honored once again, this time with a standing ovation.

\section{References}

Chen L, Chetkovich DM, Petralia RS, Sweeney NT, Kawasaki Y, Wenthold RJ, Bredt DS Nicoll RA (2000) Stargazin regulates synaptic targeting of AMPA receptors by two distinct mechanisms. Nature 408:936-943. CrossRef Medline

Isaac JT, Nicoll RA Malenka RC (1995) Evidence for silent synapses: implications for the expression of LTP. Neuron 15:427-434. Medline

Kauer JA, Malenka RC Nicoll RA (1988) A persistent postsynaptic modification mediates long-term potentiation in the hippocampus. Neuron 1:911-917. Medline

Malenka RC, Kauer JA, Zucker RS Nicoll RA (1988) Postsynaptic calcium is sufficient for potentiation of hippocampal synaptic transmission. Science 242:81-84. Medline

Malenka RC, Kauer JA, Perkel DJ, Mauk MD, Kelly PT, Nicoll RA Waxham MN (1989) An essential role for postsynaptic calmodulin and protein kinase activity in long-term potentiation. Nature 340: 554-557. CrossRef Medline

Nicoll RA (1969) Inhibitory mechanisms in the rabbit olfactory bulb: dendrodendritic mechanisms. Brain Res 14:157-172. Medline

Nicoll RA (1970a) Recurrent excitatory pathways of anterior commissure and mitral cell axons in the olfactory bulb. Brain Res 19:491493. Medline

Nicoll RA (1970b) Identification of tufted cells in the olfactory bulb. Nature 227:623-625. Medline 